\title{
Tax-Spend, Spend-Tax or Fiscal synchronization hypothesis: Evidence from Iran
}

\author{
Abbas Ali Rezaei \\ Organization of Economic Affairs and Finance In Sistan \& Balouchestan, \\ Sistan \& Balouchestan, Foreign Investment Service Center, \\ Po Box 98168-75671 Azadi, Iran \\ E-mail address: a.rezaei.a@gmail.com
}

\begin{abstract}
The relationship between revenue and government expenditure is an important subject in public economics especially for Iran country, which is suffering from persistent budget deficits. From point of view of theoretical studies, there are essentially four schools of thought on the direction of causation between government expenditure and revenue. The main purpose of this study is to investigate the Long and short Run relationship between government revenue and government expenditure in Iran Country covering data 1978- 2012 with using An Auto Regressive Distributive Lag (ARDL) Approach. The Iranian economy has been subject to a multitude of structural changes and regime shifts during the sample period. First, time series properties of the data are first analysed by Augmented Dickey-Fuller (ADF), Zivot-Andrews and Lee - Strazicich (2003, 2004) model. The results of the ADF and Lee - Strazicich models indicate that all series under investigation are nonstationary at level. However, it is evident from the results of Augmented Dickey-Fuller and Lee Strazicich tests that revenue and government expenditure are stationary at first difference because null hypotheses of unit roots for all the variables are rejected at 1 percent significance level then, we investigated causality between revenue and government expenditure by using an application of TodaYamamoto approach. Their evidence generally found unidirectional causality running from government revenue to government expenditure. So, these results consistent with the revenue-spend hypothesis. In the three stage, Autoregressive Distributeded Lag (ARDL) technique is used to describe both long run relationships and short run dynamic adjustments between government revenue and expenditure variables. The results of this paper support the Freidman (1978) hypothesis that government revenues cause expenditure and revenues have a positive causal impact on government expenditure.
\end{abstract}

Keywords: structural break; Toda-Yamamoto approach; ARDL technique; Iranian economy

JEL classification numbers: $\mathrm{C} 12, \mathrm{O} 17, \mathrm{C} 52$.

\section{INTRODUCTION}

To take a good decision and to improve their societies, the governments need to design the budget. To do its functions a government uses budget as a planning and financial tool. One of the debates of public finance is to find the relationship between government revenue and expenditure and considerable theoretical and empirical research has been carried out on this issue. If policymakers understand the relationship between government expenditure and government revenue, without a pause government deficits can be prevented. Hence the 
relationship between government expenditure and government revenue has attracted significant interest. This is due to the fact that the relationship between government revenue and expenditure has an impact on the budget deficit. Over the Past three decades, a large number of studies have investigated the relationship between government revenue and government expenditure. Understanding the relationship between government revenue and government expenditure is important from a policy point of view, especially for Asian countries, which is suffering from persistent budget deficits.

There is a budget deficit while the government revenues are less than the government expenditures. Vice versa, when the government expenditures less than its revenues it is said that the government has budget surplus. There are always the budget deficit for iran during all of years of this study. In other words, the budget deficit is a characteristic of Iran economics. Some time the governments to reduce the unemployment rate at their societies use the budget deficit policy but having the budget deficit in the long period not only is a policy but also is a problem for society that it needs to solve. To solve this problem the government should reduce its expenditures or it should increase its revenues resources. The budget revenue resources should be stationary and they must have the lowest fluctuations. Strongly dependent budget with the oil revenue shows the government have to change its expenditures or revenues. To achieve these aims the government should know the relationship between government revenues and expenditures. It has been observed that in some cases revenue increase or expenditures reduction affect on its corresponding variable and makes the adopted policy ineffective. So before to make a decision about reducing of the expenditure or increasing revenues it is important to know the amount of dependences of those variables that affect on the government expenditures. To obtain the appropriate financial policy to reduce or remove budget deficit it is necessary to find the relationship between government revenues and expenditures. The main purpose of this paper is to investigate the relationship between government revenue and expenditure in Iran for the period from 1978-2011. The paper is divided into five sections. Following this introduction, literature review of relevant studies will be presented. Section three will discuss data and methodology that is used in this research. Empirical results are reported in section four. Section five will conclude this exercise.

\section{1. Theoretical Literature Review}

The causal relationship between revenues and government expenditure is a classic problem of Public Economics. There are four propositions that can potentially explain observed spending-revenue behavior. The propositions are briefly discussed as follows: Friedman leads the tax-and-spend school, which contends that raising taxes will simply lead to more spending. Friedman (1982) [cited in Narayan (2005: 1205)] puts his point in the following way: "You cannot reduce the deficit by raising taxes Increasing taxes only results in more spending, leaving the deficit at the highest level conceivably accepted by the public. Political rule number one is government spends what government receives plus as much more as it can get away with". Also Milton Friedman (1982) suggests cutting taxes as a remedy to budget deficits, since taxes have a positive causal impact on government expenditure. According to Friedman, a cut in tax leads to higher deficits, which should influence government to reduce its level of spending, (Moalusi, 2004). Buchanan and Wagner (1977, 1978) put forward an alternative version of the tax-and-spend hypothesis. In contrast to Friedman (1978), they argue that tax increases would lead to spending reductions. The building block of the Buchanan and Wagner $(1977,1978)$ version of the tax-and-spend hypothesis is that taxpayers suffer from fiscal illusion. According to the authors, tax cuts 
lower the perceived price of government provided goods and services by the public, which in turn boosts the public demand for these goods and services. However, the public may actually incur even higher costs. One reason for this is the indirect inflation taxation that results if the government resorts to excessive money creation. Another reason is higher interest rates associated with government debt financing may crowd out private investment. To reduce expenditures, Buchanan and Wagner favor limiting the ability of the government to resort to deficit financing. In sum, while tax changes as before drive spending changes, the relationship between the two is a negative one.

The second school known as spend-and-tax school is built on the tenet that expenditure causes revenue proposed by Peacock and Wiseman (1961, 1979). According to the spendand-tax hypothesis, the level of spending is first determined by the government and then tax policy and revenue are adjusted to accommodate the desired level of spending. A version of this hypothesis is suggested by Roberts (1978), and Peacock and Wiseman (1979) according to whom crisis situations (due to for example wars, natural disasters, or deep recessions) justify temporary increases in expenditures and taxes to pay for them. However, tax increases may become permanent; reflecting an upward adjustment in the level of tax tolerance of the citizens and their attitude towards the proper size of the government after the crisis has passed. This in turn allows for a permanent increase in the level of government expenditures. Another version of this hypothesis is based on the works of Barro $(1974,1979,1986)$. In his tax smoothing hypothesis, government spending is considered as an exogenous variable to which taxes adjust. Moreover, the intertemporal budget constraint requires that an increase in current expenditures be matched by higher future taxes. Barro, therefore, rejects the notion that the taxpayers suffer from fiscal illusion. Quite the contrary, within the framework of the Ricardian equivalence theorem, he maintains that taxpayers are sophisticated, or rational, enough to see that an increase in the current debt in nothing but a delayed form of taxation. Taxpayers are, therefore, expected to fully capitalize the future tax liability. As pointed out by von Furstenberg et al. (1992), changes in spending can precede changes in taxes if a political majority raises pre-election expenditures, which are then paid for by subsequent post-election tax increases, or if they cut taxes as a compensation for earlier decisions to restrain expenditures. Since it is changes in expenditures that drive changes in taxes in this scenario, the preferred approach to fiscal deficit reduction relies on cutting expenditures.

Fiscal synchronization hypothesis as the third school of thought argues that governments may change expenditure and taxes concurrently (Meltzer \& Richard, 1981; Musgrave, 1966). This implies bidirectional causality between government expenditure and revenue. Under the fiscal synchronization hypothesis, citizens decide on the level of spending and taxes. This is done through comparing the benefits of government to citizen's marginal cost, (Narayan, 2005). Barro's (1979) tax smoothing model provided further credence to the fiscal synchronization hypothesis. His model was based on the Ricardian equivalence view that deficit financed government expenditure today results in future tax increases, (Narayan, 2005). The implication of this hypothesis is that causal relationship between government revenue and spending is bidirectional.

Finally, fourth school, fiscal neutrality school, proposed by Baghestani and McNown (1994) believe that none of the above hypotheses describes the relationship between government revenues and expenditure. Government expenditure and revenues are each determined by the long run economic growth reflecting the institutional separation between government revenues and expenditure that infers that revenue decisions are made independent are expenditure decisions. A major advocate of this view is Wildavsky (1988) who maintains that separate institutions such as the executive and legislative branches of the 
US government participate in the budgetary process to determine the level of taxation and spending. Budgeting can be incremental and adjustments can be made on the margin if these separate institutions reach a consensus on the fundamentals. In this case there is no causality between the two variables, and hence they are independent of one another.

\section{2. Empirical Literature Review}

Numerous empirical studies available on revenue and expenditure nexus all over the world but there is no consensus about the linkage between these variables. Though over the last three decades several studies have been carried out in different countries to investigate the issue in the public economics, findings vary from country to country and also within the country. Considerable empirical works have been done with respect to the four above mentioned hypotheses. Using different econometric methods, studies have reached to different results. Different studies have focused on different countries, time periods, and have used different proxy variables for government revenue and expenditure. The empirical outcomes of these studies have been varied and sometimes conflicting. The results differ even on the direction of causality and it is long-term versus short term impact on government policy. We now move on to review some of the empirical studies of the relationship between government revenue and expenditure.

Hasan and Lincoln (1997) carried out a research on this issue for United Kingdom by using cointegration technique and quarterly data from 1961-93 was used for this purpose. This study reveals that government tax revenue Granger causes government expenditures and vice versa. E.g. Shah and Baffes (1994) in their study for Latin American countries concluded bidirectional causality between government revenue and expenditure for Argentina over the 1913-1984 periods and for Mexico over the 1895-1984 periods; while for Brazil they found unidirectional causality running from revenue to expenditure. Owoye (1995) investigated the issue for the G7 countries. He found bidirectional causality for five of the seven countries and for Japan and Italy he found causality running from revenue to expenditure. Abdul Aziz and Shah Habibullah (2000) investigated causality between taxation and government spending by using an application of Toda-Yamamoto approach in Malaysia for the period 1960 to 1997.

Their evidence generally supports the existence of bidirectional causality between government spending and tax revenues. Kollias and Makrydakis (2000) examined tax and spending relationship in four countries namely; Greece, Portugal, Spain, Ireland which are comparatively poorer countries in European Union. They found that cointegration prevails in only Greece and Ireland cases and whereas there is no long run relationship in the models for Spain and Portugal. Moreover, bidirectional causality between government spending and revenue exists in Greece and Ireland. As far as Spain and Portugal cases are concerned, in the former country, causality runs from revenue to expenditure and in the later country, there is no causal link between these two important fiscal variables. Chang et al (2002) conducted a study to examine this relationship in ten industrialized countries including three newly industrialized Asian economies namely, Taiwan, South Korea and Thailand. In this study, GDP variable is also included in the model as a control variable along with government expenditures and tax variables and Johansen cointegration technique is exercised for analysis. They claimed that cointegration among the variables prevails for seven countries and found causality from government revenues to government expenditures for UK, USA, South Korea, Japan and Taiwan whereas causality runs from government expenditures to revenues for South Africa and Australia. This study also found independence between revenues and expenditures for New Zealand and Thailand. Maghyereh and Sweidan (2004) examined tax- 
spend, spend-tax and fiscal synchronization hypothesis for Jordan using annual time series data from 1969 to 2002.

The authors used real GDP as control variable along with real government expenditures and real government revenues and Granger causality test based on Multivariate ECM. They conclude evidence in favor of bidirectional causality between revenue and expenditure. The result also suggests that there is long-run interdependence between output and fiscal variables indicating effectiveness of fiscal policy in Jordan.

Carneiro et al. (2005) investigated this issue for Guinea-Bissau over the period 1981 to 2002. They found that Guinea-Bissau's experience is consistent with the "spend - tax" hypothesis. Barua (2005) examined revenue and expenditure causality in Bangladesh by using annual data over the period 1974-2004. The results of Johansen test suggest that there is a long-run relationship between government expenditure, revenue and GDP and the Granger Causality test on the corresponding Vector Error Correction (VEC) model suggests that there is no causal relationship between revenue and expenditure in the short run. It is also observed that the short run relation extends from both the fiscal variables to GDP, and not the other way around. Tsen and Kian-Ping (2005) examined this relationship in Malaysia for the period from 1965 - 2002. Augmented Dickey-Fuller and Phillips-Perron Unit root tests, Johansen cointegration and error correction models were applied to data.

The results supported tax-spend hypothesis. Government revenue was found to Granger cause expenditure in Malaysia. In another study, Narayan and Narayan (2006) found tax-andspend hypothesis for Mauritius, El Salvador, Chile, Paraguay and Venezuela. For Haiti, there is evidence for supporting the fiscal synchronization hypothesis, while for Peru, South Africa, Guatemala, Guyana, Uruguay and Ecuador there is evidence of neutrality by application of the Toda and Yamamoto (1995) test for Granger causality. Nyamongo et al. (2007) in a study of the government revenue and expenditure nexus in South Africa found different results. A monthly data was used, and modified unit root test and Vector Error Correction Model (VECM) were applied on data.

It was found that government revenue and expenditure are cointegrated, and a long-run relationship exists between them. Applying Granger causality through VECM model, it was found bidirectional Granger causality which supports fiscal synchronization hypothesis. In the short-run no Granger causality was found between variable, suggesting fiscal neutrality hypothesis in South Africa for the period of study. the study Wolde-Rufael (2008) for 13 African countries by using Toda and Yamamoto causality test show the direction of causation are mixed and his empirical evidence suggests that there was a bidirectional causality running between expenditure and revenue for Mauritius, Swaziland and Zimbabwe; no causality in any direction for Botswana, Burundi and Rwanda; unidirectional causality running from revenue to expenditure for Ethiopia, Ghana, Kenya, Nigeria, Mali and Zambia; and an undirectional causality running from expenditure to revenue for Burkina Faso only.

Chaudhuri and Sengupta (2009), by using an error-correction model and Granger causality test for southern states in India reported that the tax-spend hypothesis is supported by the analysis and also the spend-tax hypothesis is valid for some states. Ravin thirakumaran (2011) examined the relationship between government revenue and expenditure in Sri Lanka for the period from 1977-2009. A time series methodology of Engle-Granger's approach of cointegration and error correction model framework is investigated. The study concluded that bidirectional causality exists between government revenue and expenditure and there is longrun equilibrium between the two variables in Sri Lanka economy. Subhani et al. (2012) found the opposite causality direction confirming the tax-spend hypothesis. They studied the causality direction between government expenditure and revenue for Pakistan. Annual data 
for the period from 1979-2010 were used, and Granger causality was applied to variables in question. The paper found that government revenue Granger cause government expenditure in Pakistan for the period under investigation.

To the best of the author's knowledge, the evidence on the relationship between government revenue and expenditure for Iran is scarce. Zonnoor, S. H (1995) examined the growth of government expenditures and revenues in Iran over the period of $1970-1990$ in light of conventional theories as to the nature of public sector economic activity. In his study simple forms of government expenditure and tax functions are estimated. They also examined the speed of the adjustment process by estimating a simple disequilibrium model of government expenditures and receipts.

Using a constant shares model as well as a constant marginal shares model, they compared the pattern of expenditures and the revenues structure before and after the Iran's revolution.Elyasi and Rahimi (2012) found bidirectional causality between government revenue and expenditure in Iran. Annual data for the period from 1963-2007 were used, and variables were tested for stationarity. The paper included a comprehensive list of studies on causality between government revenue and expenditure for country specific and for multicountries studies. The evidence cited on the direction of causality is mixed in those studies. Different data sets, econometric methodologies and different country characteristics are some of reasons cited for the different results on the direction of causality.

\section{TODA-YAMAMOTO AUGMENTED GRANGER CAUSALITY APPROACH}

Various tests are present to check the causality among variables i.e. Granger (1969), Engle \& Granger (1987) and Johansen \& Jesulious (1990). These tests are not free from errors like they require stationarity requirements, selection of maximum lag length and they are very sensitive to model specification. It is necessary to pretest the unit root and cointegration while applying these tests. To overcome these problems, the present study applies a more robust causality technique given by Toda Yamamoto (1995) and it is further explained by Rambaldi \& Doran (1996) and Zapata \& Rambaldi (1997). The Augmented Granger Causality Approach given by Toda Yamamoto (1995) is very simple to apply and it also follows asymptotic Chi-square distribution.

The major advantage of above said approach is that, in this technique, it is not necessary to check the pre testing of the order of integration or cointegration properties among variables (Toda Yamamoto, 1995; Dolado \& Lütkepohl, 1996; Giles \& Mirza, 1999). Rambaldi \& Doran (1996) have modified Wald test that is considered more efficient when Seemingly Unrelated Regression (SUR) Model is used in the estimation. One of the attractiveness of using SUR is that it takes care of possible simultaneity bias in the system of equations.

$$
\begin{aligned}
& Y_{t}=\alpha_{0}+\beta_{1 i} \sum_{i=1}^{k} Y_{t-i}+\beta_{2 j} \sum_{j=k+1}^{d_{\max }} Y_{t-j}+\gamma_{1 i} \sum_{i=1}^{k} X_{t-i}+\gamma_{2 j} \sum_{j=K+1}^{d_{\max }} X_{t-j}+\varepsilon_{1 t} \\
& X_{t}=\alpha_{1}+\lambda_{1 i} \sum_{i=1}^{k} X_{t-i}+\lambda_{2 j} \sum_{j=k+1}^{d_{\max }} X_{t-j}+\delta_{1 i} \sum_{i=1}^{k} Y_{t-i}+\delta_{2 j} \sum_{j=K+1}^{d_{\max }} Y_{t-j}+\varepsilon_{2 t}
\end{aligned}
$$


This test has an asymptotic chi-squared distribution with $\mathrm{k}$ degrees of freedom in the limit when a VAR $[\mathrm{k}+\mathrm{dmax}]$ is estimated (where dmax is the maximal order of integration for the series in the system). Two steps are involved with implementing the procedure. The first step includes determination of the lag length $(\mathrm{k})$ and the maximum order of integration (dmax) of the variables in the system. Measures such the Akaike Information Criterion (AIC), Schwarz Information Criterion (SC), Final Prediction Error (FPE) and Hannan-Quinn (HQ) Information Criterion can be used to determine the appropriate lag order of the VAR, we use Akaike Information Criterion (AIC) and Schwarz Information Criterion (SC) to select the optimal lag to include in models. We use the Augmented Dickey-Fuller ,Zivot-Andrews and Lee - Strazicich $(2003,2004)$ tests to determine the maximum order of integration. Given the VAR(k) selected, and the order of integration dmax is determined, a levels VAR can then be estimated with a total of $\mathrm{p}=[\mathrm{k}+\mathrm{dmax}]$ lags. The second step is to apply standard Wald tests to the first $\mathrm{k}$ VAR coefficient matrix (but not all lagged coefficients) to conduct inference on Granger causality. Also, Toda and Yamamoto cannot be used if the maximum number of unit-roots in the VAR is larger than the optimal lag-length. Thus, in some cases, it might not be possible to conduct causality tests

\section{DATA AND ECONOMETRIC METHODOLOGY}

This study aims to provide empirical evidence on the relationship between government revenue and expenditure for Iran and give insights on the causality patterns. Therefore, in this paper the Toda-Yamamoto approach is used to check the causality between two variable. However before going to estimate the data it is necessary to check the unit root presence in the data and for that in this study the ADF and Zivot-Andrews and Lee - Strazicich (2003, 2004) unit root test is used in order to know the order of integration of the series. Although, to determine lag length of model, we employee Final prediction error (FPE), Akaike information criterion (AIC) and Schwarz information criterion (SC). Annual time series variables data which utilized in this paper are include the government revenue (TR) and government expenditure (GE) gathered from web site Central Bank of Iran. The logarithm of the government expenditures and government revenues are used in the empirical analysis. The transformation of the series to logarithms is intended to eliminate the problem of heteroskedasticity. Annual data for the period from 1978 - 2012 are used in this study. We select these period because time series data on government revenue and government expenditure are only available for this period.

\section{FINDINGS AND DISCUSSION}

\section{1. Augmented Dickey-Fuller Unit Root Testing for order of integration:}

Most of time series have unit root as many studies indicated including (Nelson and Polsser, 1982), and as proved by (Stock and Watson, 1988) and (Campbell and Perron, 1991) among others that most of the time series are non-stationary. The presence of a unit root in any time series means that the mean and variance are not independent of time. Conventional regression techniques based on non stationary time series produce spurious regression and statistics may simply indicate only correlated trends rather than a true relationship (Granger and Newbold, 1974). Conventional tests for identifying the existence of unit roots in a data series include that of the Augmented Dickey Fuller (ADF) $(1979,1981)$. Our main reason for 
conducting unit root tests is to determine the extra lags to be added to the vector autoregressive (VAR) model for the Toda and Yamamoto test. Prior to testing for a causality relationship between the time series, it is necessary to establish whether they are integrated of the same order. To this end in the first step of the empirical analysis, the Augmented Dickey Fuller (ADF) unit-root tests have been carried out for the both variables: government expenditure and Government Revenue, both in logarithm. The results reported in Table 1, indicate that both of the variables are nonstationary.

Table1. Augmented Dickey-Fuller Unit Root Test.

\begin{tabular}{|c|c|c|c|c|}
\hline Variable & $\begin{array}{l}\text { With } \\
\text { constant \& trend }\end{array}$ & $\begin{array}{c}\text { Critical value } \\
\qquad(5 \%)\end{array}$ & With Constant & $\begin{array}{c}\text { Critical value } \\
(5 \%)\end{array}$ \\
\hline $\begin{array}{c}\text { Government } \\
\text { Revenue }\end{array}$ & -2.22 & -3.55 & 0.616 & -2.957 \\
\hline $\begin{array}{l}\text { Government } \\
\text { Expenditure }\end{array}$ & -3.185 & -3.574 & 0.44 & -2.976 \\
\hline $\begin{array}{c}\text { First-Difference } \\
\text { Government } \\
\text { Revenue }\end{array}$ & $-4.620^{*}$ & -3.562 & $-4.581^{*}$ & -2.960 \\
\hline $\begin{array}{c}\text { First-Difference } \\
\text { Government } \\
\text { Expenditure }\end{array}$ & $-3.900^{*}$ & -3.56 & $-3.907^{*}$ & -2.960 \\
\hline
\end{tabular}

Note : $(*)$, indicate the rejection of null hypotheses in a level of $5 \%$ respectively.

\section{2. Zivot-Andrews unit root test with structural break.}

Zivot and Andrews (1992) propose a variation of Perron's (1989) original test in which the time of the break is estimated, rather than known as an exogenous phenomenon. The null hypothesis in their method is that the variable under investigation contains a unit-root with a drift that excludes any structural break, while the alternative hypothesis is that the series is a trend stationary process with a one-time break occurring at an unknown point in time. By endogenously determining the time of structural breaks, ZA argue that the results of the unit root hypothesis previously suggested by earlier conventional tests such as the ADF test may change. In this methodology, $T B$ (the time of break) is chosen to minimize the one-sided $t$ statistic of $a=1$. In other words, a break point is selected which is the least favorable to the null hypothesis. The ZA model endogenises one structural break in a series (such as $y t$ ) as follows:

$$
H_{0}: y_{t}=\mu+y_{t-1}+e_{t}
$$

$H_{1}$ :

$$
\begin{aligned}
& \operatorname{Model}(A): y_{t}=\hat{\mu}^{A}+\hat{\theta}^{A} D U_{t}\left(\widehat{T}_{b}\right)+\hat{\beta}^{A} t+\hat{\alpha}^{A} y_{t-1}+\sum_{j=1}^{k} \hat{C}_{j}^{A} \Delta y_{t-j}+\hat{e}_{t} \\
& \operatorname{Model}(B): y_{t}=\hat{\mu}^{B}+\hat{\beta}^{B} t+\hat{\gamma}^{B} D T_{t}\left(\widehat{T}_{b}\right)+\hat{\alpha}^{B} y_{t-1}+\sum_{j=1}^{n} \hat{C}_{j}^{B} \Delta y_{t-j}+\hat{e}_{t}
\end{aligned}
$$


$\operatorname{Model}(C): y_{t}=\hat{\mu}^{C}+\hat{\theta}^{C} D U_{t}\left(\widehat{T}_{b}\right)+\hat{\beta}^{C} t+\hat{\gamma}^{C} D T_{t}\left(\widehat{T}_{b}\right)+\hat{\alpha}^{C} y_{t-1}+\sum_{j=1}^{k} \hat{C}_{j}^{C} \Delta y_{t-j}+\hat{e}_{t}(6)$

Equation (4), which is referred to as model $\mathrm{C}$ by ZA, accommodates the possibility of a change in the intercept as well as a trend break. ZA also consider two other alternatives where a structural break impacts on the intercept only (model A) or trend only (model B). Model $\mathrm{C}$ is the least restrictive compared to the other two models; In above equations $D U t$ is a sustained dummy variable capturing a shift in the intercept, and DTt is another dummy variable representing a shift in the trend occurring at time $T B$. Zivot and Andrews (ZA) (1992) argue that the results of the conventional unit root tests may be reversed by endogenously determining the time of structural breaks. The null hypothesis in the Zivot and Andrews test is a unit root without any exogenous structural change. The alternative hypothesis is a stationary process that allows for a one-time unknown break in intercept and/or slope. The alternative hypothesis is that the series, yt, is I(0) with one structural break. TB is the break date, and the dummy variables are defined as follows:

$$
D U_{t}=\left\{\begin{array}{ll}
1 & \text { if } t>T B_{1} \\
0 & \text { if } t \leq T B_{1}
\end{array} \quad \text { and } \quad D T_{t}=\left\{\begin{array}{c}
t-T B_{1} \text { if } t>T B_{1} \\
0 \text { if } t \leq T B_{1}
\end{array}\right.\right.
$$

The null is rejected if the $a$ coefficient is statistically significant. The optimal lag length is determined on the basis of the t-test or SBC. The "trimming region" where we search for the minimum $t$ ratio is assumed to be within $0.05 \mathrm{~T}-0.95 \mathrm{~T}$ or $0.05 T \leq T B 1 \leq 0.95 T$. Based on the results reported in Tables 1, ZA models indicate that all series under investigation are non-stationary.

The same unit root tests have been applied to the first difference of the variables and in most cases we rejected the null hypothesis of unit root. Hence, we maintain the null hypothesis that each variable is integrated of order one or I(1). The reported t statistics in Table 1 for $\hat{\mu}, \hat{\beta}, \hat{\theta}, \hat{\gamma}$ and $\hat{\alpha}$ are significant in the majority of cases. Given the fact that all of the estimated coefficients for the indicator and trend dummy variables are statistically significant, one can argue that the estimated structural break dates are indeed statistically significant.

\section{3. Minimum Lagrange Multiplier (LM) Unit Root Test with Two Endogenous Structural Breaks for order of integration}

However, recent contributions to the literature suggest that such tests may incorrectly indicate the existence of a unit root, when in actual fact the series is stationary around a onetime structural break (Zivot and Andrews, 1992; Pahlavani, et al, 2006). Therefore I this section we applied Lee and Strazicich with Two Endogenous Structural Breaks for determine the order of integration.

Lee and Strazicich (2003) consider the data-generating process (DGP) as follows:

$$
y=\delta Z_{t}+e_{t}, e_{t}=\beta e_{t-1}+\varepsilon_{t}
$$


Table 2. The Zivot-Andrews test results.

\begin{tabular}{|c|c|c|c|c|c|c|c|c|c|c|}
\hline & Series & $\mathrm{T}$ & $T_{b}$ & Lag & $\hat{\mu}$ & $\hat{\beta}$ & $\hat{\theta}$ & $\hat{\alpha}$ & $\hat{\gamma}$ & $\hat{c}$ \\
\hline \multirow{4}{*}{$\begin{array}{c}\text { MODEL } \\
\text { (A) }\end{array}$} & LTR & 33 & 1994 & 1 & $\begin{array}{c}2.3 \mathrm{I} \\
(3.92)\end{array}$ & $\begin{array}{c}0.06 \\
(3.21)\end{array}$ & $\begin{array}{l}0.46 \\
(3.21)\end{array}$ & $\begin{array}{c}-0.36 \\
(-3.67)\end{array}$ & --- & $\begin{array}{c}0.09 \\
(0.56)\end{array}$ \\
\hline & LGE & 33 & 1994 & 1 & $\begin{array}{c}1.70 \\
(3.85)\end{array}$ & $\begin{array}{c}0.03 \\
(2.69)\end{array}$ & $\begin{array}{c}0.37 \\
(3.40)\end{array}$ & $\begin{array}{c}-0.24 \\
(-3.45)\end{array}$ & --- & $\begin{array}{c}-0.04 \\
(-0.27)\end{array}$ \\
\hline & ALTR & 32 & 1990 & 1 & $\begin{array}{l}0.22 \\
(2.63)\end{array}$ & $\begin{array}{l}-0.01 \\
(-3.2)\end{array}$ & $\begin{array}{c}0.6 \\
(4.03)\end{array}$ & $\begin{array}{c}-1.42-\cdot \\
(-5.7)\end{array}$ & --- & $\begin{array}{l}0.23 \\
(1.39)\end{array}$ \\
\hline & $\Delta \mathrm{LGE}$ & 32 & 1991 & 1 & $\begin{array}{c}0.2 \\
(2.99)\end{array}$ & $\begin{array}{c}-0.01 \\
(-2.960\end{array}$ & $\begin{array}{l}0.41 \\
(3.69)\end{array}$ & $\begin{array}{l}-1.16 \\
(-4.61)\end{array}$ & --- & $\begin{array}{c}0.05 \\
(0.32)\end{array}$ \\
\hline \multirow{4}{*}{$\begin{array}{l}\text { MODEL } \\
\text { (B) }\end{array}$} & $\begin{array}{l}\text { LTR } \\
\text {. }\end{array}$ & 33 & 2008 & 1 & $\begin{array}{l}1.35 \\
(2.51)\end{array}$ & $\begin{array}{c}0.05 \\
(2.65)\end{array}$ & --- & $\begin{array}{c}-0.22 \\
(-2.43)\end{array}$ & $\begin{array}{c}-0.04 \\
(-1.44)\end{array}$ & $\begin{array}{c}0.14 \\
(0.83)\end{array}$ \\
\hline & LGE & 33 & 1986 & 1 & $\begin{array}{l}1.86 \\
(2.07)\end{array}$ & $\begin{array}{l}-0.003 \\
(-0.08)\end{array}$ & --- & $\begin{array}{c}-0.22 \\
(-2.26)\end{array}$ & $\begin{array}{l}0.05 \\
(1.15)\end{array}$ & $\begin{array}{l}0.29 \\
(1.58)\end{array}$ \\
\hline & ALTR & 32 & 1995 & 1 & $\begin{array}{c}-0.10 \\
(-0.56)\end{array}$ & $\begin{array}{l}0.02 \\
(1.74)\end{array}$ & --- & $\begin{array}{l}-1.06 \\
(-3.91)\end{array}$ & $\begin{array}{c}-0.04 \\
(-1.86)\end{array}$ & $\begin{array}{l}0.03 \\
(0.2)\end{array}$ \\
\hline & $\triangle \mathrm{LGE}$ & 29 & 1995 & 4 & $\begin{array}{c}-0.67 \\
(-4.57)\end{array}$ & $\begin{array}{c}0.07 \\
(5.54)\end{array}$ & --- & $\begin{array}{l}-1.65^{*} \\
(-6.12)\end{array}$ & $\begin{array}{c}-0.08 \\
(-5.52)\end{array}$ & $\begin{array}{c}0.35 \\
(1.72)\end{array}$ \\
\hline \multirow{4}{*}{$\begin{array}{l}\text { MODEL } \\
\text { (C) }\end{array}$} & LTR & 33 & 1993 & 1 & $\begin{array}{l}3.21 \\
(2.65)\end{array}$ & $\begin{array}{c}0.05 \\
(2.73)\end{array}$ & $\begin{array}{c}0.59 \\
(2.69)\end{array}$ & $\begin{array}{c}-0.46 \\
(-2.81)\end{array}$ & $\begin{array}{c}0.04 \\
(1.15)\end{array}$ & $\begin{array}{c}0.2 \\
(1.07)\end{array}$ \\
\hline & LGE & 33 & 1985 & 1 & $\begin{array}{c}1.81 \\
(2.09)\end{array}$ & $\begin{array}{l}0.04 \\
(0.65)\end{array}$ & $\begin{array}{c}-0.18 \\
(-1.10)\end{array}$ & $\begin{array}{c}-0.25 \\
(-2.38)\end{array}$ & $\begin{array}{c}0.11 \\
(0.15)\end{array}$ & $\begin{array}{c}0.28 \\
(1.54)\end{array}$ \\
\hline & $\Delta \mathrm{LTR}$ & 32 & 1990 & 1 & $\begin{array}{c}0.65 \\
(2.51)\end{array}$ & $\begin{array}{c}-0.06 \\
(-2.34)\end{array}$ & $\begin{array}{l}0.78 \\
(4.4)\end{array}$ & $\begin{array}{l}-1.50 * * \\
(-6.14)\end{array}$ & $\begin{array}{c}0.05 \\
(1.74)\end{array}$ & $\begin{array}{c}0.29 \\
(1.77)\end{array}$ \\
\hline & $\triangle \mathrm{LGE}$ & 29 & 1994 & 4 & $\begin{array}{c}-0.56 \\
(-3.45)\end{array}$ & $\begin{array}{l}0.06 \\
(4.53)\end{array}$ & $\begin{array}{l}0.22 \\
(2.05)\end{array}$ & $\begin{array}{l}-1.94 * * \\
(-5.59)\end{array}$ & $\begin{array}{c}-0.08 \\
(-5.27)\end{array}$ & $\begin{array}{c}0.58 \\
(2.78)\end{array}$ \\
\hline
\end{tabular}

Notes : For Government Revenue and Government Expenditure we assumed break in both Intercept and trend. The $5 \%$ critical value, test is -5.080 , For Government Revenue and Government Expenditure. They are obtained using 1-lag for both tests. Zivot-Andrews test the null hypothesis of unit-root.

where $\mathrm{Zt}$ is a vector of exogenous variables and $\varepsilon_{t}$ is an iid Gaussian error term. In the following, we will consider a model allowing for two changes in level and trend, i.e. 
Model A allows for two shifts in level and is given by $Z_{t}=\left[1, t, D_{1 t}, D_{2 t},\right]^{\prime}$ and Model $C$ allows for two changes in the level and trend and is described $Z_{t}=\left[1, t, D_{1 t}, D T_{1 t}, D_{2 t}, D T_{2 t}\right]^{\prime}$ where Djt and DTjt for $\mathrm{j}=1,2$ are dummies with Djt $=1$ for $\mathrm{t} \geq \mathrm{TB}_{\mathrm{j}}+1$ and 0 otherwise and $\mathrm{DT}_{\mathrm{jt}}=\mathrm{t}-\mathrm{T}_{\mathrm{Bj}}$ for $\mathrm{t} \geq \mathrm{T}_{\mathrm{Bj}}+1$ and 0 otherwise. $\mathrm{T}_{\mathrm{Bj}}$ denotes the $\mathrm{j}^{\text {th }}$ break date.

The DGP given in equation (3) allows for breaks under the null $(\beta=1)$ and the alternative $(\beta<1)$. Lee and Strazicich (2003) use the following regression to obtain the LM unit root test statistic:

$$
\Delta y_{t}=\delta^{\prime} \Delta Z_{t}+\varnothing \tilde{S}_{t-1}+\sum_{i=1}^{k} \gamma_{i} \Delta \tilde{S}_{t-j}+u_{t}
$$

With $\tilde{S}_{t}=y_{t}-\tilde{\psi}_{t}-Z_{t} \widetilde{\delta}, t=2, \ldots \ldots, T$ the detrended series. $\tilde{\delta}$ Are the coefficients from the regression of $\Delta y_{t}$ on $\Delta Z_{t}, \tilde{\psi}_{t}=y_{t}-Z_{1} \tilde{\delta}$ where $\mathrm{y}_{1}$ and $\mathrm{Z}_{1}$ correspond to the first observations. The lagged terms $\Delta \tilde{S}_{t-j}$ are included to correct for serial correlation. From equation (4), the LM test statistics are given by the t-statistics testing the null hypothesis $\emptyset=0$. The break dates are determined endogenously by a grid search over all possible dates, i.e. once $10 \%$ of the endpoints are eliminated, such that they minimize the test statistic. The critical values are tabulated in Lee and Strazicich $(2003,2004)$ for the single-break and twobreak cases respectively.

Table 3. Lee-Strazicich Minimum LM Two-Break Unit-Root Test.

Note: * indicates the rejection of the null hypothesis at the $1 \%$ level of significance, ${ }^{* *}$ at $5 \%$. See Lee and Strazicich (2003) for the critical values.

\begin{tabular}{|c|c|c|c|c|c|c|c|c|c|}
\hline & Series & $T B_{1}$ & $T B_{2}$ & $S_{t-1}$ & $D T_{1 t}$ & $\mathrm{~B}_{1 t}$ & $\mathrm{~B}_{2 t}$ & $D T_{2 t}$ & $\mathrm{k}$ \\
\hline \multirow{4}{*}{$\begin{array}{c}\text { MODEL } \\
(\mathrm{A})\end{array}$} & LGE & 1991 & 2008 & $\begin{array}{c}-0.09 \\
(-1.54)\end{array}$ & ---- & $\begin{array}{c}-0.03 \\
(-0.17)\end{array}$ & $\begin{array}{c}0.3 \\
(1.75)\end{array}$ & --- & 1 \\
\cline { 2 - 10 } & LTR & 1988 & 1999 & $\begin{array}{c}-0.15 \\
(-1.95)\end{array}$ & ---- & $\begin{array}{c}-0.42 \\
(-1.78)\end{array}$ & $\begin{array}{c}0.54 \\
(2.32)\end{array}$ & --- & 1 \\
\cline { 2 - 10 } & $\Delta \mathrm{LGE}$ & 1990 & 2001 & $\begin{array}{c}-1.22^{*} \\
(-4.50)\end{array}$ & ---- & $\begin{array}{c}0.3 \\
(2.14)\end{array}$ & $\begin{array}{c}-0.02 \\
(-0.15)\end{array}$ & --- & 1 \\
\cline { 2 - 10 } & $\Delta \mathrm{LTR}$ & 1989 & 2002 & $\begin{array}{c}-1.44^{*} \\
(-5.51)\end{array}$ & ---- & $\begin{array}{c}0.48 \\
(2.48)\end{array}$ & $\begin{array}{c}-0.10 \\
(-0.54)\end{array}$ & --- & 1 \\
\hline
\end{tabular}

Following Lee and Strazicich, the two-break minimum LM unit root test are applied to determine the order of integration both Model A and B for the major macroeconomic variables of the IRAN economy. Table 2 provides the results. The estimation results fail to reject the null hypothesis of a unit root for both variables. The same unit root tests have been applied to the first difference of the variables and in all cases we rejected the null hypothesis of unit root. Hence, we maintain the null hypothesis that each variable is integrated of order one or I(1). 
After the ADF, Zivot-Andrews test and Lee and Strazicich Unit Root tests and having determined that $\mathrm{d}_{\max }=1$, we Following the modeling approach described earlier. In the two step to determine lag length of VAR(k), we employee Final prediction error (FPE), Akaike information criterion (AIC) and Schwarz information criterion (SC), lag selection criteria are used. The result of selecting optimal lag length of VAR is reported in Table 3. FPE, AIC and $\mathrm{SC}$ information criterion indicate that lag order of VAR (k) is one. According to lag length of VAR process, we employee modified Wald test for VAR(2) to get results of causality test between entrepreneurship and unemployment.

Table 4. Lags under different criteria for VAR model.

\begin{tabular}{cccc}
\hline Lag & FPE & AIC & SC \\
\hline 0 & 0.1281 & 3.621321 & 3.715617 \\
1 & $0.000658^{*}$ & $-1.651708^{*}$ & $-1.368819^{*}$ \\
2 & 0.000816 & -1.441754 & -0.970273 \\
3 & 0.000784 & -1.491999 & -0.834925 \\
\hline \hline 4 & 0.000919 & -1.358647 & -0.509981 \\
\hline \hline
\end{tabular}

Notes: *indicates lag order selected by the criterion; FPE: Final prediction error, AIC: Akaike information criterion, SC: Schwarz information criterion,

\section{RESULTS OF TODA YAMAMOTO AUGMENTED GRANGER CAUSALITY TECHNIQUE}

The present study applies Toda Yamamoto Augmented Granger Causality approach to examine the causal nexus among Entrepreneurship to unemployment rate.

Table 5. Todo- Yamamoto Causality (modified Wald) test results.

\begin{tabular}{|c|c|c|c|c|c|}
\hline Null hypothesis & $\operatorname{Lag}(\mathbf{k})$ & $\mathbf{k}+\mathbf{d} \max$ & $\begin{array}{l}\text { MWald } \\
\text { statistics }\end{array}$ & p-values & Decision \\
\hline $\begin{array}{l}\mathrm{H}_{0}: \text { GE does not } \\
\text { Granger cause } \mathrm{TR}\end{array}$ & 1 & 2 & 1.427 & 0.232 & Do not reject $H_{0}$ \\
\hline $\begin{array}{l}\mathrm{H}_{0} \text { : TR does not } \\
\text { Granger cause GE }\end{array}$ & 1 & 2 & 2.736 & $0.09^{*}$ & Reject $H_{0}$ \\
\hline
\end{tabular}

*indicate rejection of the null at the $10 \%$ level

The empirical results of Granger Causality test based on Toda and Yamamoto (1995) methodology is estimated through MWALD test and reported in Table 4. The estimates of MWALD test show that, there is strong evidence of causality running from Government Revenue (TR) to Government Expenditure (GE) at the $10 \%$ level of significance. The results do not reveal causality from Government Expenditure to Government Revenue. Therefore, we can conclude that there is a uni-directional of causality that runs from Government Revenue (TR) to Government Revenue for IRAN. 


\section{COINTEGRATION ANALYSIS WITH STRUCTURAL BREAKS}

As had been noted as far back as 1989 by Perron, ignoring the issue of potential structural breaks can render invalid the statistical results not only of unit root tests but of cointegration tests as well. Kunitomo (1996) explains that in the presence of a structural change, traditional cointegration tests, which do not allow for this, may produce "spurious cointegration". In the present research, therefore, considering the effects of potential structural breaks is very important, especially because the Iranian economy has been faced with structural breaks like revolution and war in addition to some policy changes. Saikkonen and Lütkepohl (2000 a,b,c) have proposed a test for cointegration analysis that allows for possible shifts in the mean of the data-generating process. Because many standard types of data generating processes exhibit breaks caused by exogenous events that have occurred during the observation period, they suggest that it is necessary to take into account the level shift in the series for proper inference regarding the cointegrating rank of the system. They argued that "structural breaks can distort standard inference procedures substantially and, hence, it is necessary to make appropriate adjustment if structural shifts are known to have occurred or are suspected" (2000b: 451). The Saikkonen and Lütkepohl (SL) test investigates the consequences of structural breaks in a system context based on the multiple equation frameworks of Johansen-Jeslius, while earlier approaches like Gregory-Hansen (1996) considered structural break in a single equation framework and others did not consider the potential for structural breaks at all. According to Saikkonen and Lütkepohl (2000b) and Lütkepohl and Wolters (2003), an observed n-dimensional time series yt $=(y 1 t, \ldots, y n t)$, yt is the vector of observed variables $(t=1, \ldots, T)$ which are generated by the following process:

$$
y_{t}=\mu_{0}+\mu_{1} t+\gamma_{1} d_{1 t}+\gamma_{2} d_{2 t}+\gamma_{3} d_{3 t}+\delta D t_{o t}+\delta_{2} D u_{1 t}+x_{t}
$$

where DT0t and DU1t are impulse and shift dummies, respectively, and account for the existence of structural breaks.and account for the existence of structural breaks. $D T 0 t$ is equal to one, when $\mathrm{t}=\mathrm{T} 0$, and equal to zero otherwise. Step (shift) dummy $\left(D u_{1 t}\right)$ is equal to one when ( $\mathrm{t}>\mathrm{T} 1)$, and is equal to zero otherwise. The parameters $\gamma_{i}(\mathrm{I}=1,2,3), \mu_{0}, \mu_{1}$, and $\delta$ are associated with the deterministic terms. The seasonal dummy variables $d 1 t, d 2 t$, and $d 3 t$, are not relevant to this research since our data are yearly. According to SL (2000b), the term $x t$ is an unobservable error process that is assumed to have a VAR (p) representation as follows:

$$
x_{t}=A_{1} x_{t-1}+\cdots+A_{p} x_{t-p}+\varepsilon_{t} \quad, \quad t=1,2
$$

By subtracting xt-1 from both sides of the above equation and rearranging the terms, the usual error correction form of the above equation is given by:

$$
\Delta x_{t}=\prod x_{t-1}+\sum_{j=1}^{p-1} \Gamma_{j} \Delta x_{t-j}+u_{t}
$$

This equation specifies the cointegration properties of the system. In this equation, $u t$ is a vector white noise process; $x t=y t-D t$ and $D t$ are the estimated deterministic trends. The rank of $\Pi$ is the cointegrating rank of $x t$ and hence of yt (SL, 2000b). The possible options in the SL procedure, as in Johansen, are three: a constant, a linear trend term, or a linear trend orthogonal to the cointegration relations. In this methodology, the critical values depend on 
the kind of the above-mentioned deterministic trend that included in the model. More interestingly, in SL, the critical values remain valid even if dummy variables are included in the model, while in the Johansen test; the critical values are available only if there is no shift dummy variable in the model. The SL approach can be adopted with any number of (linearly independent) dummies in the model. It is also possible to exclude the trend term from the model; that is, $\mu=0$ maybe assumed a priori. In this methodology, as in Johansen's, the model selection criteria (SBC, AIC, and HQ) are available for making the decision on the VAR order. In the following section, we have applied SL tests for the cointegration rank of a system in the presence of structural breaks.

\section{1. Empirical Results based on the SL Procedures}

As explained above Saikkonen and Lütkepohl (2000b) derived the likelihood ratio (LR) test in order to determine the number of cointegrating relations in a system of variables, by considering for the presence of the potential structural breaks. We now apply a maximum likelihood approach; based on SL; for testing and determining the long-run relationship in the model under investigation. As mentioned earlier, in this procedure SL assumed that the break point is known a priori. In the last section, we determined the time of the break endogenously by Zivot-Andrews (1992) procedure. Following the SL procedure we consider three cases: impulse dummy and shift with intercept included; impulse dummy and shift with trend and intercept included; and finally, impulse dummy and shift with a trend statistically independent (orthogonal) to cointegration relation included.

Table 6. Saikkonen and Lutkephol cointegration test results.

\begin{tabular}{|c|c|c|c|c|c|}
\hline \multirow{2}{*}{ null hypothesis } & LR & \multicolumn{3}{|c|}{ Critical values } \\
\cline { 4 - 6 } & & $10 \%$ & $5 \%$ & $1 \%$ \\
\hline \multirow{2}{*}{$\begin{array}{c}\text { Intercept } \\
\text { included (C) }\end{array}$} & $r=0$ & 12.07 & $10.47^{*}$ & 12.26 & 16.10 \\
\cline { 2 - 6 } & $r=1$ & 1.36 & 2.98 & 4.13 & 6.93 \\
\hline $\begin{array}{c}\text { Intercept and } \\
\text { trend } \\
\text { included } \\
(\mathrm{C} / \mathrm{T})\end{array}$ & $r=0$ & 11.58 & 13.88 & 15.76 & 19.17 \\
\cline { 2 - 6 } & $r=1$ & 1.44 & 5.47 & 6.79 & 9.73 \\
\hline $\begin{array}{c}\text { Trend } \\
\text { orthogonal } \\
\text { to } \\
\text { cointegration } \\
\text { relation } \\
(\mathrm{C} / \mathrm{O})\end{array}$ & $r=0$ & 10.86 & $8.18^{*}$ & $9.84^{* *}$ & 13.48 \\
\cline { 2 - 6 } & $r=1$ & ---- & ---- & --- & --- \\
\hline
\end{tabular}

Note: * ** Indicates that the corresponding null hypothesis is rejected at $10 \%$ and $5 \%$ level. Critical values are tabulated by SL (2000b). The optimal number of lags (searched up to 1 lags) is determined by the SBC. 
The cointegration results in these three cases are presented in Tables (6) The optimal number of lags is determined by SBC, which is more appropriate for the short span of the data. The hypothesis of the long-run relationship among non-stationary variables is tested and the result is reported in Table (6). These tables indicates that the hypothesis of no cointegration $(r=0)$ is rejected at the $10 \%$ significance level at $\mathrm{C}$ (Intercept included ) and $\mathrm{CO}$ (Trend orthogonal to cointegration relation) Models. therefore the existence of one cointegration vector is not rejected in any of the three cases mentioned above.

\section{ESTIMATED LONG AND SHORT RUN COEFFICIENTS USING THE ARDL APPROACH}

There are several methods available to test for the existence of long-run equilibrium relationship among time series variables. The most widely used methods include Engle and Granger (1987) test, fully modified OLS procedure of Phillips and Hansen's (1990), maximum likelihood based Johansen $(1988,1991)$ and Johansen - Juselius (1990) tests. These methods require that the variables in the system are integrated of order one i.e. I(1). In addition, these methods suffer from low power and do not have good small sample properties. Due to these problems, a newly developed autoregressive distributed lag (ARDL) approach to co-integration has become popular in recent years. An ARDL model is a general dynamic specification, which uses the lags of the dependent variable and the lagged and contemporaneous values of the independent variables, through which the short-run effects can be directly estimated, and the long-run equilibrium relationship can be indirectly estimated.

This study employs ARDL approach to co-integration following the methodology proposed by Pesaran and Shin (1999). This methodology is chosen as it has certain advantages on other co-integration procedures. For example, it can be applied regardless of the stationary properties of the variables in the sample. Secondly, it allows for inferences on long-run estimates which are not possible under alternative co-integration procedures. Finally, ARDL Model can accommodate greater number of variables in comparison to other Vector Autoregressive (VAR) models.

ARDL analysis is based on the interpretation of three equations: Dynamic equation, Long-run equation and Error-correction equation. The first step is to examine the existence of a long-run relationship among all variables in the equation under examination. Conditional upon cointegration is confirmed, in the second stage, the long-run coefficients and the shortrun coefficients are estimated using the associated ARDL and in the three stage An error correction model (ECM), are estimated to explain the short-run Relationship between variable .

Table (7) shows the results from Dynamic equation. Having estimated the dynamic equation, to ensure the presence of long-run relation Benerji - Dolado and Master test has been used. The calculated $t$ is

$$
t=\frac{\sum \hat{a}_{i}-1}{\sum S \hat{a}_{i}}=\frac{0 / 48099-1}{0 / 063971}=-8 / 11
$$

which is greater than the critical absolute value of Benerji - Dolado and Master (-3.28). So, the null hypothesis is rejected and the existence of long-run relation among the variables is realized. 
Table 7. Results from estimating dynamic model of ARDL.

\begin{tabular}{|c|c|c|c|}
\hline \multicolumn{4}{|c|}{ Dependent Variable: Log( Government Expenditure) } \\
\hline Regressors & Coefficient & $\mathrm{t}$ & p-value \\
\hline LGE(-1) & 0.48 & 7.51 & $\mathbf{0 . 0 0}$ \\
\hline LTR & 0.50 & 8.29 & $\mathbf{0 . 0 0}$ \\
\hline $\mathbf{C}$ & 0.349 & 3.99 & 0.00 \\
\hline \multicolumn{4}{|l|}{$\mathbf{R}^{2}=\mathbf{0} / 99$} \\
\hline \multicolumn{4}{|l|}{ Serial Correlation $=\mathbf{0 . 2 2}(\mathbf{0 . 6 3})$} \\
\hline \multicolumn{4}{|l|}{ Functional Form $=0.04(\mathbf{0 . 8 2 4})$} \\
\hline Heteroscedasticity $=\mathbf{1 . 0 3}(\mathbf{0 . 5 9 6})$ & & & \\
\hline
\end{tabular}

The results summarized in Table (8) indicate that the revenue government Has Positive and significant effect on the government expenditure in Iran. The estimated coefficient provides the income elasticity which shows the expected signs. i.e. $1 \%$ increase in revenue government would lead to increase the government expenditure to Iran by 0.97 percent.

Table 8. Result from estimating the long-run relation.

\begin{tabular}{|c|c|c|c|}
\hline \multicolumn{4}{|c|}{ Dependent Variable: Log( Government Expenditure) } \\
\hline Regresses & Coefficient & t & (p-value) \\
\hline C & 0.67 & 4.47 & 0.00 \\
\hline LTR & 0.97 & 6.63 & 0.00 \\
\hline
\end{tabular}

An error correction model (ECM), are estimated to explain the short-run Relationship between revenue and government expenditure in Iran. The findings, which are summarized in table (9), show that the estimated coefficients of model in short run are less than the 
estimated coefficients in long run. The results illustrate that the short-run changes in explanatory variable is significant. It can be seen that the revenue government has the shortand -long run effects on the government expenditure in standard level of significance. Moreover, the revenue governments show positive and significant impacts on government expenditure. The results also show that the error correction coefficient denotes the appropriate sign and is statistically significant. It indicates that 0.51 of deviation of the government expenditure from its long-run equilibrium level is corrected each year, which is a relatively slow adjustment rate.

Table 9. Result from estimating ECM.

\begin{tabular}{|c|c|c|c|}
\hline Regressors & Coefficient & $\mathbf{t}$ & p-value \\
\hline dLTR & $\mathbf{0 . 5 0 3}$ & $\mathbf{8 . 9 2}$ & $\mathbf{0 . 0 0}$ \\
\hline dC & $\mathbf{0 . 3 4}$ & $\mathbf{3 . 9 9}$ & $\mathbf{0 . 0 0}$ \\
\hline Ecm $_{-1}$ & $-\mathbf{0 . 5 1}$ & $\mathbf{- 8 . 1 1}$ & $\mathbf{0 . 0 0}$ \\
\hline \multicolumn{3}{|c|}{$\mathbf{R}^{2}=\mathbf{0 . 6 9}$} & $\bar{R}^{2}=\mathbf{0 . 6 7}$ \\
\hline
\end{tabular}

Finally, we have examined the stability of the long-run parameters together with the short-run movements for the equations. For test, we relied on cumulative sum of recursive residuals (CUSUM) and cumulative sum squares (CUSUMSQ) tests proposed by Borensztein, et al. (1998). The same procedure has been utilized by Pesaran and Pesaran (1997), Suleiman (2005) and Mohsen et al. (2002) to test the stability of the long-run coefficients. The tests applied to the residuals of the ECM model. Graphical representations of CUSUM and CUSUM square are shown in Figure 1 and 2. According to Bahmani and Oskooee, (2004) the null hypothesis (i.e. that the regression equation is correctly specified) cannot be rejected if the plot of these statistics remains within the critical bounds of the $5 \%$ significance level. 


\section{Plot of Cumulative Sum of Recursive Residuals}

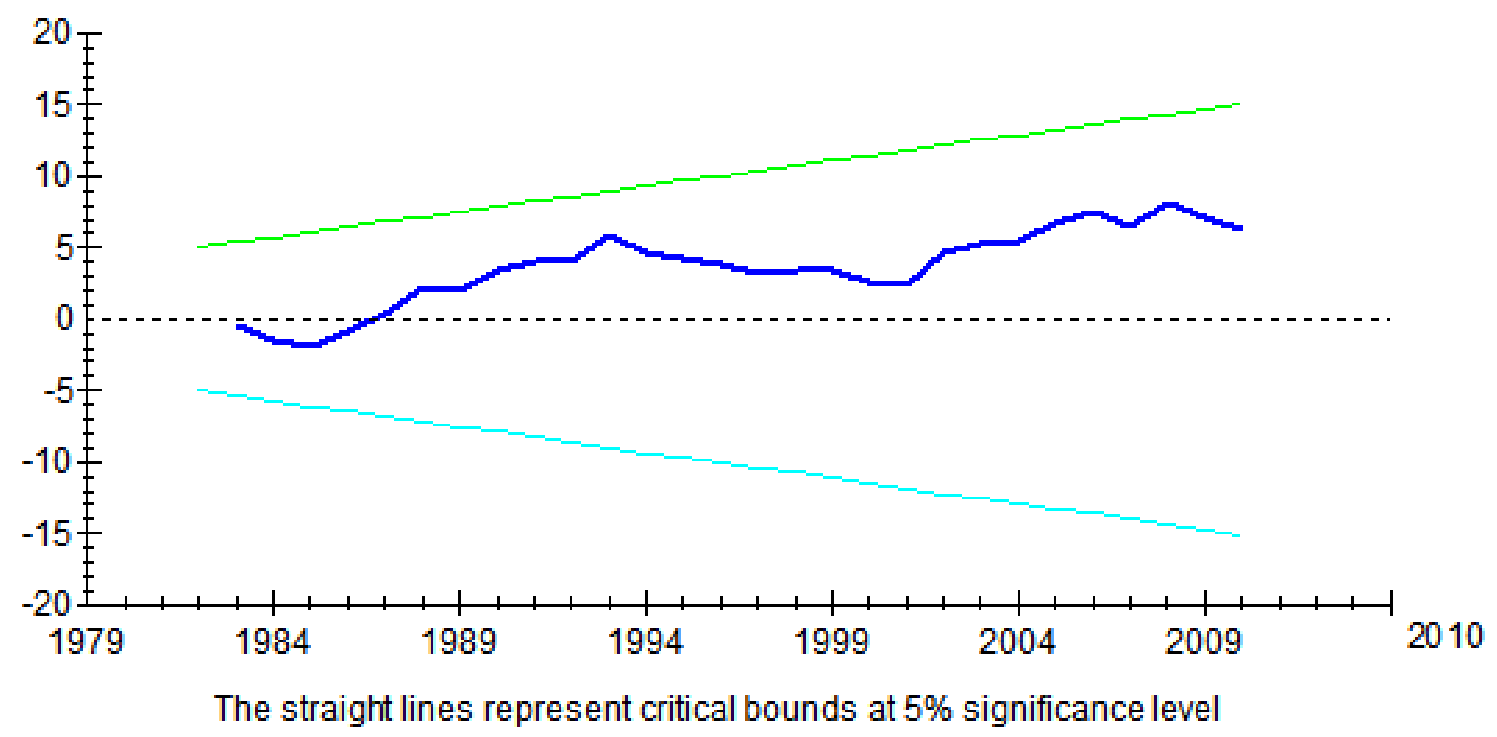

Figure 1. CUSUM Plots for test of stability.

Plot of Cumulative Sum of Squares of Recursive Residuals

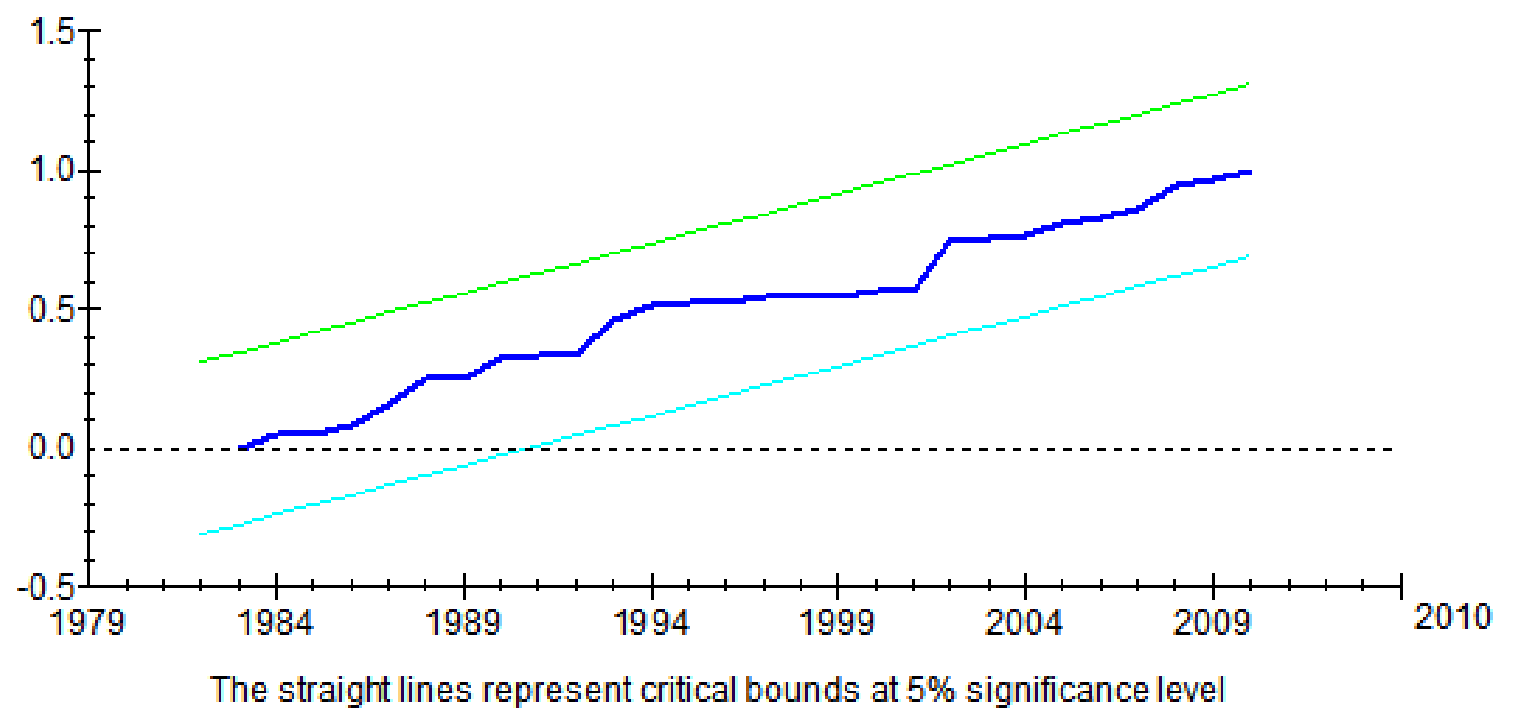

Figure 2. CUSUMSQ Plots for test of stability.

It can be seen from the figure that the plot of CUSUM stay within the critical $5 \%$ bound for all equations and CUSUMSQ statistics does not exceed the critical boundaries that confirms the long-run relationships between financial variables and also shows the stability of co-efficient. 


\section{SUMMARY AND CONCLUSIONS}

This study is an attempt to Analysis of Long and Short Run Relationship among revenue and government expenditure in Iran: An Auto Regressive Distributive Lag (ARDL) Approach for Iran. To analysis this issue, annual data are exploited for the period 1978-2011. Iran has long history of fiscal imbalance and failed to meet the expenditure with the total collected revenues. There are different theoretical viewpoints on the linkage between government spending and revenue. For example, Freidman (1978) argues that revenue causes expenditure and Barro (1979) as well as Peacock and Wiseman (1979) are of the views that government spending enhances government revenue.

The determination of the causal ordering between these two macroeconomic aggregates is vital to ensure enactment of appropriate tax policies and the effectiveness of fund management. We have applied time series econometric techniques such as; unit root analysis with and without structural break. Final prediction error (FPE), Akaike information criterion (AIC) and Schwarz information criterion (SC) for determine lag length of model and Toda Yamamoto Granger causality test and ARDL technique for Analysis of Long and Short Run Relationship among revenue and government expenditure. Both unit root tests ADF, ZivotAndrews and Lee and Strazicich unit root test found the variables to be integrated of order one. Toda - Yamamoto Granger causality test found unidirectional causality running from government revenue to government expenditure and ARDL technique showed existed positive Relationship among revenue and government expenditure in Long and Short Run.

So, these results consistent with the revenue-spend hypothesis. The results of this paper support the Freidman (1978) hypothesis that government revenues cause expenditure and revenues have a positive causal impact on government expenditure.

\section{References}

[1] Al-Yousif Y., Indian Economic Journal 48(2) (2000).

[2] Anderson W., M.S. Wallace J.T. Warner, Southern Economic Journal 52 (1986) 630-639.

[3] Baghestani H., R. McNown, Southern Economic Journal 60 (1994) 311-322.

[4] Cheng Benjamin S., Latic American Countries 23(2) (1999) 184-192.

[5] Furstenberg George M., von R. Jaffery Green, Jin Ho Jeong, The Review of Economics and Statistics 2 (1986) 179-188.

[6] Johansen S., Journal of Economic Dynamics and Control 12(1) (1988) 231-54.

[7] Johansen S., Juselius K., Oxford Bulletin of Economics and Statistics 52(2) (1990) 169-210.

[8] Joulfaian D., R. Mookerjee, Public Finance 45 (1990) 109-117.

[9] Kunitomo N., Japanese Economic Review 47(1) (1996) 79-109.

[10] Lee J., Strazicich M. C., Appalachian State University Working Papers, (2004) 04-17.

[11] Leybourne S. J., Newbold P., Applied Economics, 35(9) (2003) 1117-1121.

[12] Lütkepohl H., Wolters J., Dynamics 7 (2003) 711-733 
[13] Lutkepohl H. (2004). Vector Autoregressive and Vector Error Correction Model, in Lutkepohl, H. and M. Kratzig (ed.), Applied Time Series econometrics, Cambridge University Press.

[14] Owoye O., Applied Economic Letters 2 (1995) 19-22.

[15] Pahlavani M., International Journal of Applied Econometrics and Quantitative Studies 2-3 (2005).

[16] Pahlavani M., Wilson E. J., A. Valadkhani, International Journal of applied Business and Economic Research 4(1) (2006) 23-44.

[17] Peacock S. M., J. Wiseman, Public Finance Quarterly 7 (1979) 3-23.

[18] Perron P., Journal of Econometrics 80(2) (1997) 355-385.

[19] Ram R., Southern Economic Journal 54(3) (1988) 763-69.

[20] Saikkonen P., Lütkepohl H. (a), Econometric Theory 16(3) (2000) 373-406.

[21] Saikkonen P., Lütkepohl H. (b), Journal of Business and Economic Statistics 18(4) (2000) 451-464.

[22] Saikkonen P., Lütkepohl H. (c), Journal of Time Series Analysis 21 (2000) 435-456.

[23] Zivot E., Andrews D., Journal of Business and Economic Statistics 10 (1992) 251-70.

[23] Schwarz G., Annals of Statistics 6 (1978) 461-64.

[24] Zivot E., Andrews D. W. K., Journal of Business and Economic Statistics 10(3) (1992) 251-270. 